\section{BREWSTER'S WARBLER IN SASKATOON}

Many birders consider warblers to be the creme de la creme of the world of birds. Their vivid colour patterns make most individuals of this subfamily of birds particularly attractive when the birder is lucky enough to obtain a good view. In the Saskatoon area, warbler-watching during spring migration depends greatly upon the weather. When the weather has been warm and sunny and the nights clear, then most warblers bypass our city. Warbler aficionados await spring rains when stormy weather overnight sends flocks of warblers to city parks and residential areas for shelter.

On the weekend of 24 \& 25 May, 1997 frequent intervals of rain brought a good variety of songbirds to the Saskatoon district. Following 18 hours of non-stop birding on our annual May Day Bird Count, I was rather tired on Sunday morning but woke in time to join Patrick Bulman as he led a Saskatoon Nature Society field hike along the Meewasin Trail atop the riverbank of the South Saskatchewan River in Saskatoon.

As we passed the hilltop on the riverbank next to the university president's residence, Patrick called my attention to an unusual warbler sitting in the open on the edge of some shrubbery at a distance of about 3 $\mathrm{m}$. The warbler had a yellow crown, bluish-gray back, white underparts with a smudge of yellow on the breast and two yellow wingbars. These characteristics immediately identified it as a Brewster's Warbler, a type of warbler I had previously never had the privilege to observe.
The Brewster's Warbler is not a unique species but the more common hybrid of two rare Saskatchewan species, the Golden-winged Warbler and Blue-winged Warbler. A less frequent hybrid with genetically recessive characteristics is called the Lawrence's Warbler.

The Golden-winged Warbler nests regularly as far west as Manitoba's Riding Mountain National Park. There are 14 Saskatchewan records listed in the Atlas of Saskatchewan Birds, of which two showed up in the Saskatoon region. The Blue-winged Warbler regularly nests no closer than south-eastern Minnesota and only four Saskatchewan sightings are listed in the Saskatchewan atlas. According to the newly published bird guide All the Birds of North America the Blue-winged Warbler is "increasing to north" whereas the Golden-winged Warbler is "seriously declining by displacement and hybridization with blue-winged warbler." These comments suggest that Saskatchewan birders may look forward to discovering more hybrids of these two species straying into this province in future years.

1. Smith, Alan. 1996. Atlas of Saskatchewan Birds. Special Publication No. 22, Nature Saskatchewan, Regina.

2. Griggs, Jack. 1997. All the Birds of North America. Harper Perennial, New York.

3. Farrand, John. 1983. The Audubon Society Master Guide to Birding, Volume 3. Alfred Knopf Inc., New York.

- STAN SHADICK, 304-1008 Temperance St., Saskatoon, SK S7N ON6 